\title{
Variations of surface ozone at Ieodo Ocean Research Station in the East China Sea and the influence of Asian outflows
}

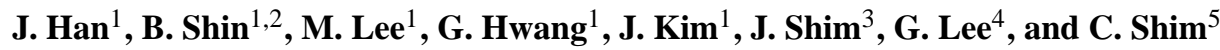 \\ ${ }^{1}$ Department of Earth \& Environmental Sciences, Korea University, Seoul, South Korea \\ ${ }^{2}$ Environmental Meteorology Research Division, National Institute of Meteorological Sciences, Jeju, South Korea \\ ${ }^{3}$ Coastal Disaster Research Center, Korea Institute of Ocean Science \& Technology, Ansan, South Korea \\ ${ }^{4}$ Department of Environmental Science, Hankuk University of Foreign Studies, Yongin, South Korea \\ ${ }^{5}$ Korea Environment Institute, Sejong, South Korea
}

Correspondence to: M. Lee (meehye@korea.ac.kr)

Received: 1 May 2015 - Published in Atmos. Chem. Phys. Discuss.: 19 June 2015

Revised: 16 October 2015 - Accepted: 23 October 2015 - Published: 12 November 2015

\begin{abstract}
Ieodo Ocean Research Station (IORS), a research tower ( $\sim 40$ ma.s.l.) for atmospheric and oceanographic observations, is located in the East China Sea $\left(32.07^{\circ} \mathrm{N}\right.$, $\left.125.10^{\circ} \mathrm{E}\right)$. The IORS is almost equidistant from South Korea, China, and Japan and, therefore, it is an ideal place to observe Asian outflows without local emission effects. The seasonal variation of ozone was distinct, with a minimum in August (37 ppbv) and two peaks in April and October (62 ppbv), and was largely affected by the seasonal wind pattern over east Asia. At IORS, six types of air masses were distinguished with different levels of $\mathrm{O}_{3}$ concentrations by the cluster analysis of backward trajectories. Marine air masses from the Pacific Ocean represent a relatively clean background air with a lowest ozone level of $32 \mathrm{ppbv}$, which was most frequently observed in summer (July-August). In spring (March-April) and winter (December-February), the influence of Chinese outflows was dominant with higher ozone concentrations of 62 and 49 ppbv, respectively. This study confirms that the influence of Chinese outflows was the main factor determining $\mathrm{O}_{3}$ levels at IORS and its extent was dependent on meteorological state, particularly at a long-term scale.
\end{abstract}

\section{Introduction}

Ozone $\left(\mathrm{O}_{3}\right)$ and its photochemical derivative, $\mathrm{OH}$, are primary oxidants and key players determining oxidation capacity within the troposphere (e.g., Berchet et al., 2013; Seinfeld and Pandis, 2006). A short-lived greenhouse gas, $\mathrm{O}_{3}$ also affects climate change and air quality (e.g., Berchet et al., 2013; Brasseur et al., 1999; IPCC, 2013; Jacobson, 2012). Exposure to high $\mathrm{O}_{3}$ levels is known to increase human mortality rates (Bell and Dominici, 2008; Chang et al., 2010), reduce agricultural yields, and damage natural ecosystems (e.g., Bell et al., 2011; Karnosky et al., 2007; Schaub et al., 2005; Wang and Mauzerall, 2004). Tropospheric $\mathrm{O}_{3}$ is primarily transported from the stratosphere upon tropopause folding and produced by in situ photochemical reactions involving carbon monoxide $(\mathrm{CO})$ and hydrocarbons in the presence of nitrogen oxides $\left(\mathrm{NO}_{x}\right)$ (Brasseur et al., 1999). Ozone is also lost by photochemical reactions and deposition to the Earth's surface. As a result, the lifetime of $\mathrm{O}_{3}$ ranges from about a week in summer to several months in winter, which permits $\mathrm{O}_{3}$, along with other pollutants, to be transported over long distances. In previous studies, ozone levels were observed to be enhanced episodically in polluted air masses from continental outflow in remote regions of the North Atlantic and North Pacific oceans (e.g., Fischer et al., 2011; Lin et al., 2012; Parrish et al., 2009; Zhang et al., 2008).

Particularly, east Asia has experienced a rapid development in economy and industry, from which emissions of $\mathrm{O}_{3}$ precursors such as $\mathrm{NO}_{x}$ and VOCs have gradually increased (Huang et al., 2013; Monks et al., 2009; Zhao et al., 2013) and the emission of $\mathrm{O}_{3}$ and its precursors in east Asia is expected to increase further in the near future (Zhao et al., 2013; Ohara et al., 2007). As a result, the study region be- 


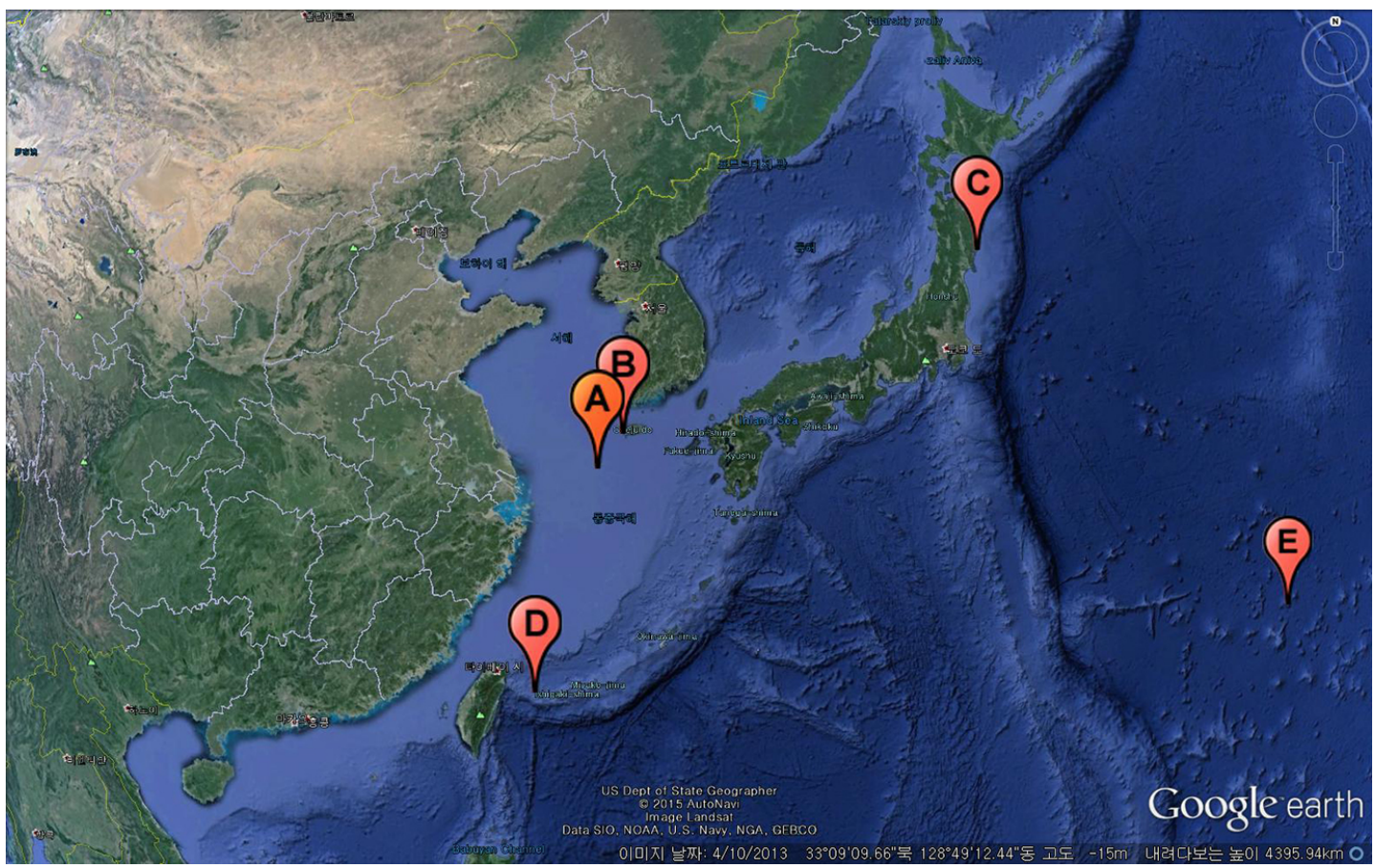

Figure 1. Geographical locations of (a) Ieodo Ocean Research Station, (b) Gosan, Korea, (c) Ryori, (d) Yonagunijima, and (e) Minamitorishima, Japan.

came a hot spot for high $\mathrm{O}_{3}$ and intensive measurements have been performed there to chart $\mathrm{O}_{3}$ and the effects it has in conjunction with climate change. Over the North Pacific Ocean, ozone has been measured on remote islands (Kato et al., 2001; Parrish et al., 2012; Tanimoto et al., 2009; Wada et al., 2011), from ships (Ridder et al., 2012; Watanabe et al., 2005) and by aircraft (Dupont et al., 2012; Kotchenruther et al., 2001; Walker et al., 2010; Zhang et al., 2008).

The impact of continental outflow upon background $\mathrm{O}_{3}$ is substantial in northeast Asia (Akimoto et al., 1996; Kondo et al., 2008; Tanimoto et al., 2008; Wada et al., 2011; Yamaji et al., 2006). This impact has similarly been detected near the western US (Fischer et al., 2011; Lin et al., 2012; Parrish et al., 2009). Walker et al. (2010) estimated that Asian anthropogenic outflow and lightning-derived $\mathrm{NO}_{x}$ emissions contributed at least 7.2 and $3.5 \mathrm{ppbv}$ to $\mathrm{O}_{3}$ concentration, respectively, in the North Pacific Ocean and western North America. In addition, Zhang et al. (2008) assessed that $\mathrm{O}_{3}$ in western North America was increased by Asian outflow 5-7 ppbv during spring 2006. The results of these studies indicate $\mathrm{O}_{3}$ concentrations in the North Pacific Rim are regularly affected by Asian outflow. Therefore, it is critical to understand the impact of continental outflows from east Asia on $\mathrm{O}_{3}$ and oxidizing power over the North Pacific Ocean. Since IORS is located in the East China Sea $\left(32.07^{\circ} \mathrm{N}, 125.10^{\circ} \mathrm{E}\right)$ (Fig. 1) and almost equidistant from nearby South Korea, China, and Japan, it is an ideal place to observe Asian outflows without local effects (Hwang et al., 2008; Shin et al., 2007). In this study, we present long-term measurements of $\mathrm{O}_{3}$ at IORS, located in the boundary zone between the Yellow and East China Sea. Then, we describe their characteristic variations and evaluate the continental influence on the regional background concentrations of $\mathrm{O}_{3}$.

\section{Methodology}

Ieodo Ocean Research Station is an unmanned research tower ( $\sim 40 \mathrm{~m}$ a.s.l.) for atmospheric and oceanographic observations. It was built on rock $36 \mathrm{~m}$ below sea level by the Korea Institute of Ocean Science and Technology (KIOST) in 2003 (Moon et al., 2010; Shim et al., 2004). $\mathrm{O}_{3}$ has been measured at IORS since June 2003. In addition, meteorological parameters have been monitored, which include air pressure, air temperature, relative humidity, wind speed and direction, and visibility. $\mathrm{O}_{3}$ was measured by an UV photometric analyzer (49C, Thermo Inc., USA) using the absorption of $\mathrm{UV}$ radiation at $253.7 \mathrm{~nm}$ by $\mathrm{O}_{3}$ molecules. The analyzer was installed in a dry lab of the main deck, which is $29 \mathrm{~m}$ a.s.l. Ambient air was pulled underneath the main deck through a $7 \mathrm{~m}$ PFA tubing (6 $\mathrm{mm}$ outer diameter). The detection limit of the instrument was $1.0 \mathrm{ppbv}$. Calibration was done about once every 2 months with an internal ozonator. In addition, the ozone analyzer was inter-compared with an identical instrument, which was calibrated against the primary standard. The two instruments were run side by side using a common inlet. The correlation coefficient of the two 
measurements was 0.99 in the range between 10 and $90 \mathrm{ppbv}$ and ambient measurements were scaled using the relationship between the two.

The data logger stored $10 \mathrm{~min}$ averages. There were power failures and system malfunction at IORS when it was hit by typhoon several times. Thus, raw data were first filtered manually and then the measurements bigger and smaller than $2 \sigma$ (standard deviation) of the average for 10 neighboring values were eliminated. This method is widely used to remove local effects for long-term period measurement (Cvitaš et al., 2004). Statistical analysis was conducted using R (v.3.0.1) (R Core Team, 2014).

Backward trajectories arriving at 100 and $1500 \mathrm{~m}$ a.s.l. were calculated for $40 \mathrm{~h}$ every 00:00, 06:00, 12:00, and 24:00 UTC (03:00, 09:00, 18:00, and 21:00 local time) using the NOAA Air Resources Laboratory (ARL) Hybrid SingleParticle Lagrangian Integrated Trajectory (HYSPLIT) model (version 4) (Draxler and Rolph, 2003, http://www.arl.noaa. gov/ready/hysplit4.html) with NCEP Final Analyses (FNL) 6-hourly archived data. Isentropic trajectory was selected as it was believed to reflect a more realistic vertical motion for an adiabatic atmosphere. A time period of $40 \mathrm{~h}$ was selected because it was long enough to capture regional transport patterns in the northwestern Pacific and short enough to minimize trajectory errors. The results for 100 and $1500 \mathrm{~m}$ showed no meaningful differences and so the following discussion will be based on $1500 \mathrm{~m}$.

\section{Ozone variations}

The mean concentration of 10 min $\mathrm{O}_{3}$ measurements was $52 \mathrm{ppbv}$ with a maximum of $128 \mathrm{ppbv}$. The variation of monthly means is presented for 8 years, from June 2003 to December 2010 (Fig. 2), during which $\mathrm{O}_{3}$ increased $\sim 2.8 \%$ year $^{-1}$ until 2009 and slightly decreased afterwards. The long-term trend of $\mathrm{O}_{3}$ at IORS is consistent with recent findings of slowdown in the increase of $\mathrm{O}_{3}$ concentrations observed in Japanese background stations at Mt. Happo and others (Parrish et al., 2012). This hemispheric baseline likely affects $\mathrm{O}_{3}$ distributions at IORS. Additionally, the vertical column density of tropospheric $\mathrm{NO}_{2}$ was reported to be decreased over east Asia in 2009, as observed by satellites GOME-2 and SCIAMACHY (Itahashi et al., 2014). In the same context, emissions of $\mathrm{NO}_{x}$ sharply increased in east Asia after 2000 mostly from China, but then slowed down in 2009 (Tanimoto et al., 2009; Zhao et al., 2013). Gu et al. (2013) pointed out that the stagnation of $\mathrm{NO}_{x}$ emissions in 2009 was associated with an economic recession in China.

The $\mathrm{O}_{3}$ concentrations of IORS were compared with those of other remote sites in east Asia and the North Pacific for the same period: Gosan in Korea (National Institute of Environmental Research), and Ryori, Yonagunijima, and Minamitorishima in Japan (World Data Centre for Greenhouse Gases, WDCGG; http://ds.data.jma.go.jp/gmd/

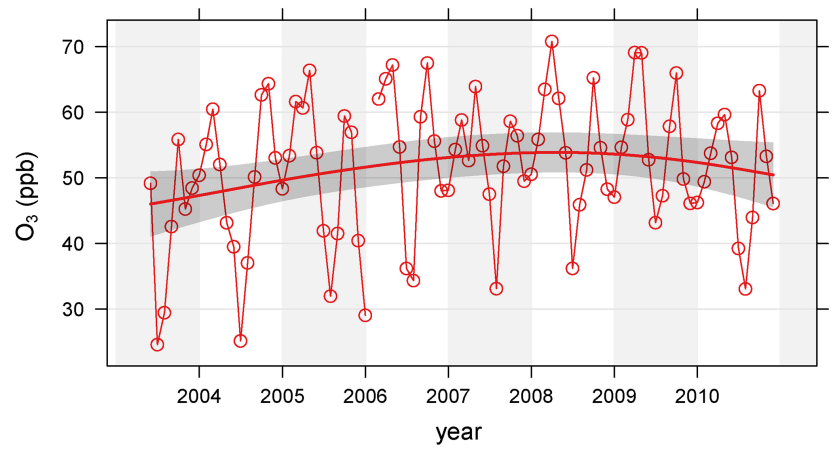

Figure 2. Monthly mean $\mathrm{O}_{3}$ concentrations at IORS, from June 2003 to December 2010, with smoothed trend (thick line) and estimated $95 \%$ confidence interval (gray shading).

wdcgg/) (Fig. 1). The diurnal and seasonal variations of 8year averaged $\mathrm{O}_{3}$ are presented here in Fig. 3. The averaged $\mathrm{O}_{3}$ concentrations of IORS, Gosan, Ryori, Yonagunijima, and Minamitorishima were 52, 39, 40, 39, and $27 \mathrm{ppbv}$, respectively. In these remote sites, the level of averaged $\mathrm{O}_{3}$ concentrations decreased with increased distance from China. At IORS, $\mathrm{O}_{3}$ mixing ratios show the minimum at 09:00 local time (LT) and reached to the broad maximum at 17:00 LT. The daytime build-up of $\mathrm{O}_{3}$ was $5 \mathrm{ppbv}$, which was much smaller than that in urban areas, but implied in situ photochemical production for $\mathrm{O}_{3}$ in the marine boundary layer of the remote site (Fig. 3a). While diurnal patterns of $\mathrm{O}_{3}$ concentration stayed unchanged through seasons, their background concentrations were clearly different, being the highest in spring and the lowest in the summer monsoon season. The daytime build-up of $\mathrm{O}_{3}$ at Gosan in the southern island of Korea and Ryori, located at the northeasterly edge of Japan, were 8 and $6 \mathrm{ppbv}$, respectively, significantly greater than $2 \mathrm{ppbv}$ at Yonagunijima (Fig. 3b). Among the five sites, the $\mathrm{O}_{3}$ concentration decreased in the afternoon only at Minamitorishima, implying $\mathrm{O}_{3}$ destruction. Considering $\mathrm{O}_{3}$ loss is generally observed under low $\mathrm{NO}_{x}$ conditions in the remote marine boundary layer (MBL) (Ayers et al., 1996), these variations indicate that IORS including other remote sites in east Asia were influenced by continental outflows. In the study region, the high concentration of $\mathrm{O}_{3}$ was reported to be attributed to transport of ozone or its precursors mainly from China (Tanimoto et al., 2008).

At IORS, the monthly averaged $\mathrm{O}_{3}$ concentrations were the highest in April and October (62 ppbv) and lowest in August (37 ppbv) (Fig. 3c). The $\mathrm{O}_{3}$ concentrations remained high during March-May, resulting in a broad spring peak which was in contrast to a sharp fall peak. This is in accordance with a typical pattern that has been observed in other remote sites over northeast Asia during the past decades (Chan et al., 2002; Jaffe et al., 1996; Kanaya et al., 2015; Kondo et al., 2008; Oltmans and Levy II, 1994; Tanimoto et al., 2005, 2009; Watanabe et al., 2005; Weiss-Penzias et al., 
(a)

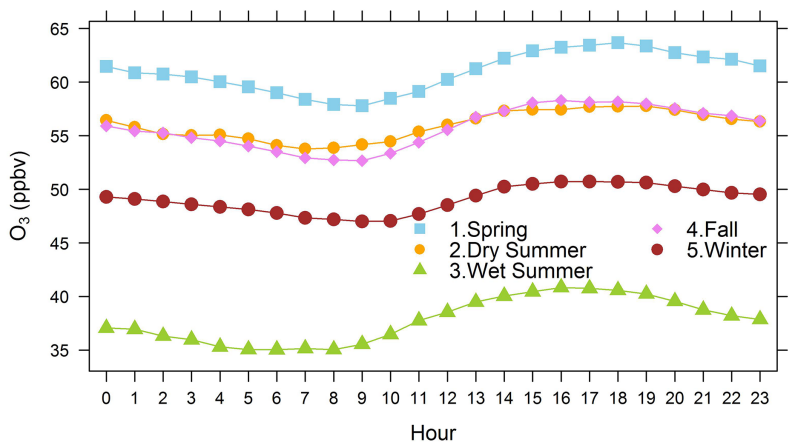

(b)

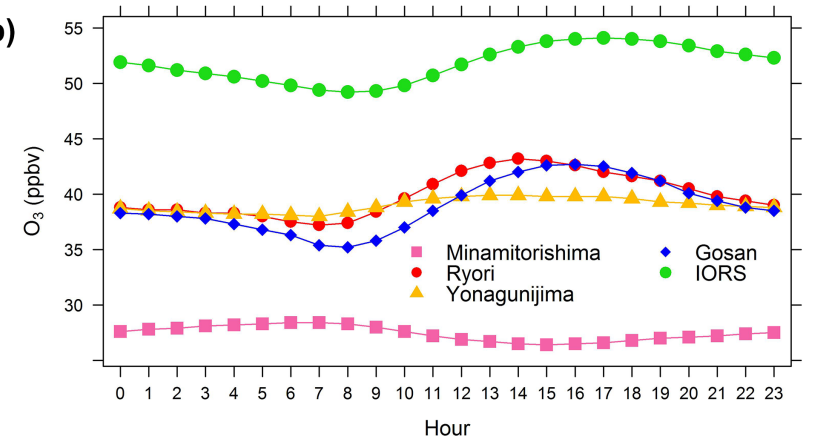

(c)

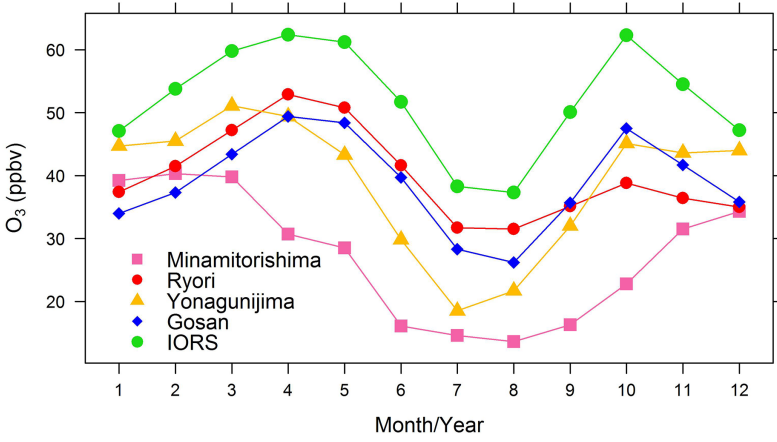

Figure 3. Comparison of diurnal and seasonal variations of $\mathrm{O}_{3}$ concentrations at remote sites in the northwest Pacific region including IORS, Gosan, Yonagunijima, Ryori, and Minamitorishima. All data were averaged for 8 years (2003-2010) and seasons were divided into spring (May-April), dry summer (May-June), wet summer (July-August), fall (September-November), and winter (December-February). (a) Diurnal variations of $\mathrm{O}_{3}$ at IORS in different seasons, (b) diurnal variations of $\mathrm{O}_{3}$ at five sites, and (c) monthly variations of $\mathrm{O}_{3}$ at five sites.

2004). In particular, the second peak of $\mathrm{O}_{3}$ was the most noticeable at IORS along with Gosan in October, which was also observed in previous studies (Kanaya et al., 2015; Tanimoto et al., 2005). It is also noteworthy that outlier levels were the highest and the maximum concentration (128 ppbv) was observed in July (Fig. 4a). In summer, the study region is under the influence of the Asian monsoon system which brings moist air from the Pacific Ocean. Meteorological parameters, including relative humidity, wind speed, and visi-

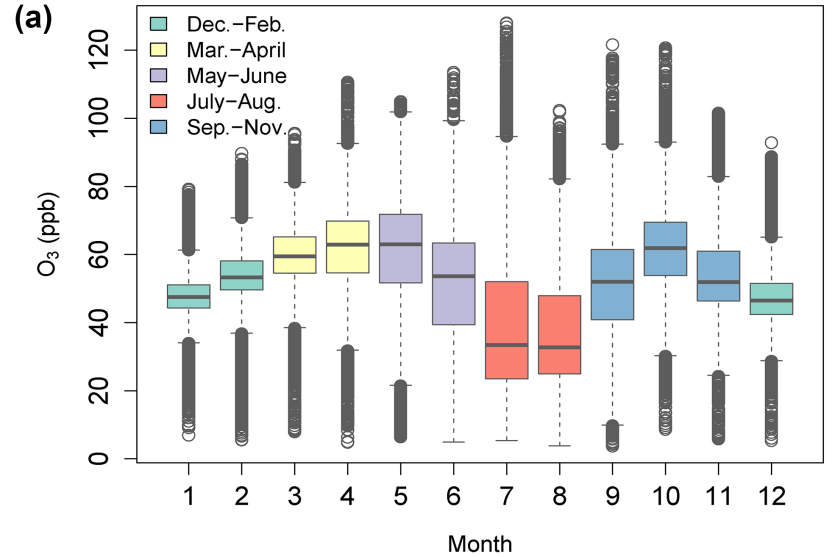

(b)
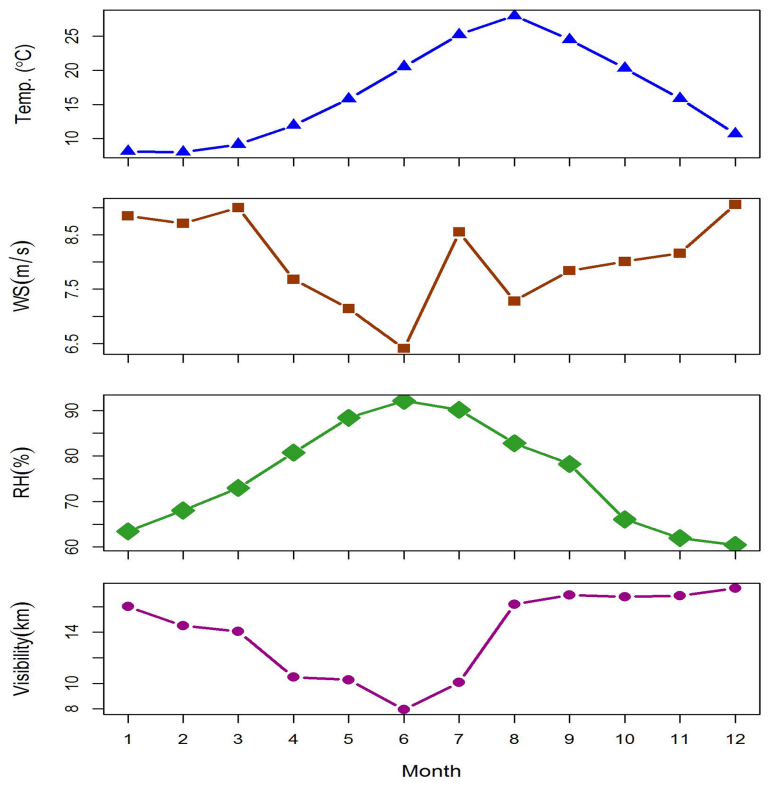

Figure 4. (a) Monthly variations of $\mathrm{O}_{3}$ presented with median, interquartile range (IQR), 1.5 IQR, and outliers, and (b) monthly distributions of temperature, relative humidity, wind speed, and visibility at IORS.

bility, indicate a clear shift in air mass from pre-monsoon to monsoon season (Fig. 4b). At IORS, $\mathrm{O}_{3}$ concentration was noticeably decreased during summer, even though the temperature was high. Likewise, the $\mathrm{O}_{3}$ level at Gosan was at a minimum in summer, when the levels of precursors were the lowest with heavy rainfall. To examine seasonal characteristics of $\mathrm{O}_{3}$ distributions, all measured species were divided into five seasons: March-April, May-June (pre-monsoon period), July-August, September-November, and DecemberFebruary. The seasonal wind patterns are presented in Fig. 5.

$\mathrm{All}_{3}$ measurements showed bimodal distribution, with a little shoulder on the larger peak (Fig. 6a). In seasonal distributions, the smaller peak ( $25 \mathrm{ppbv}$ ) was the main mode of the summer monsoon season. As shown in Fig. 5, southerly winds were dominant during July-August ( $82 \%$ ) under the 
(a)

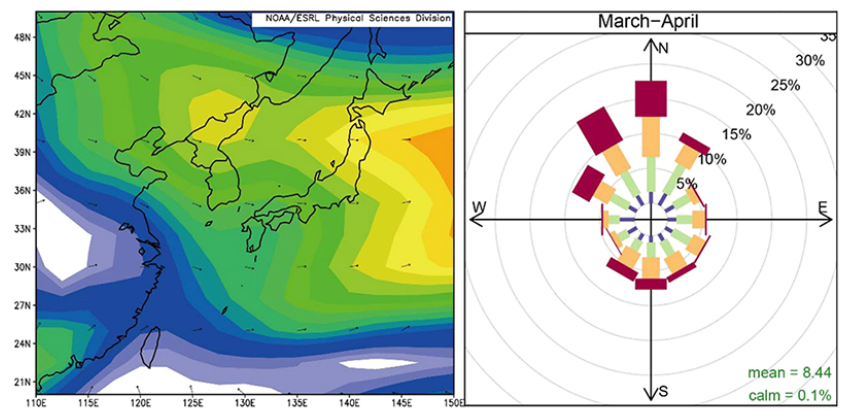

(c)
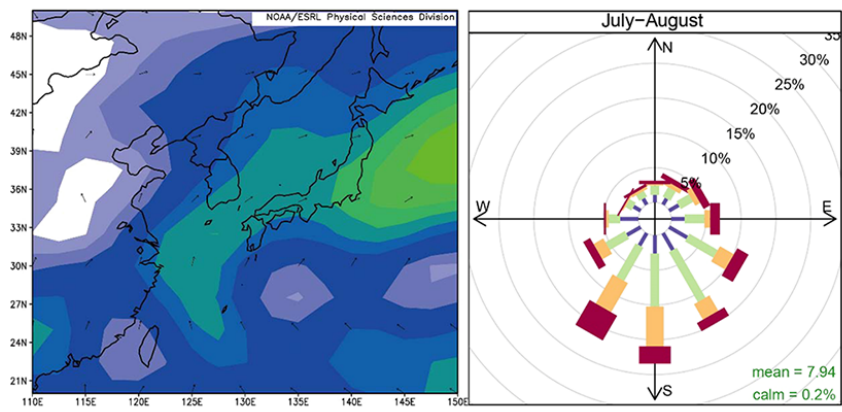

(e)
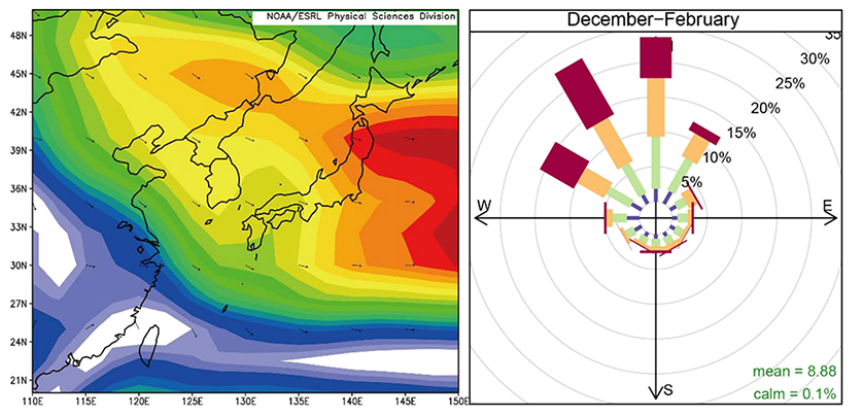

(b)
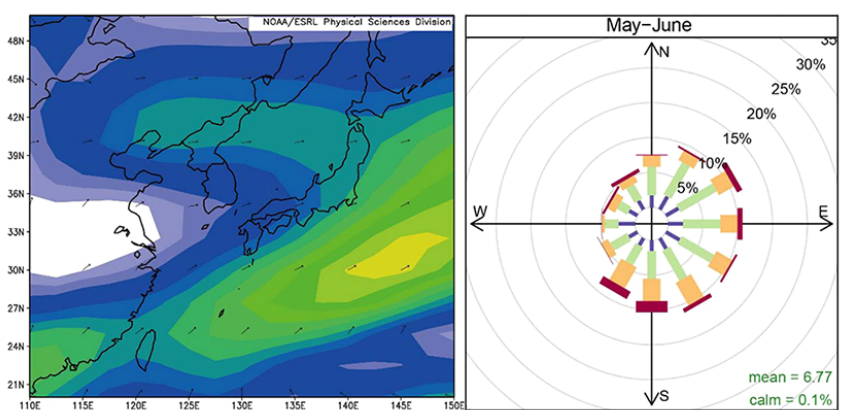

(d)
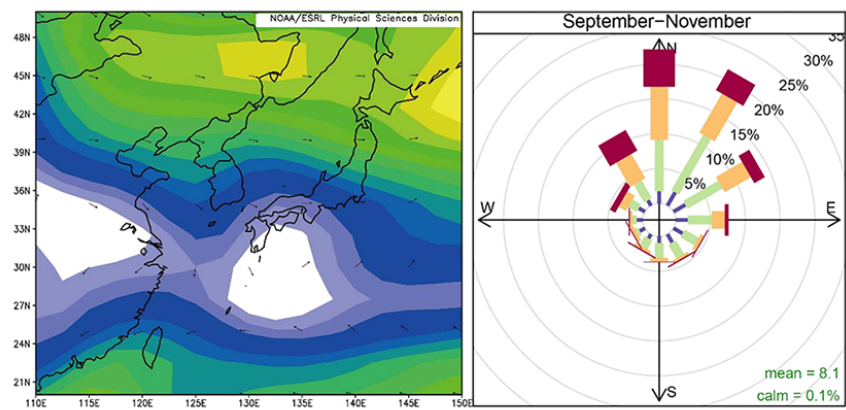

calm $=0.1 \%$

Figure 5. The left panel for contour maps presenting NCEP/NCAR Reanalysis wind speed in color and wind vector at $850 \mathrm{mb}$ in east Asia from 2004 to 2010 and the right panel for wind roses measured at IORS during (a) March-April, (b) May-June, (c) July-August, (d) September-November, and (e) December-February.

influence of North Pacific High. This pattern reveals that the decrease in $\mathrm{O}_{3}$ was associated with the aged marine air masses brought by the North Pacific High or tropical cyclones (Fig. 5c). In addition to aged air masses, precipitation had scavenged $\mathrm{O}_{3}$ precursors, possibly leading to lowered $\mathrm{O}_{3}$ concentrations (Hou et al., 2015). It was also observed that $\mathrm{O}_{3}$ was decreased in Beijing and Shanghai during the summer monsoon season (Safieddine et al., 2013). In May-June, the mode concentration was the highest at $65 \mathrm{ppbv}$ with the least frequency (Fig. 6c). It is a transition period from continental air mass to oceanic air mass and, as a result, the stagnant conditions which had developed under high temperatures without prevailing wind (Fig. 5b), led to elevated $\mathrm{O}_{3}$ concentrations. The mode concentration was the second highest ( 59 ppbv) in spring, which is characterized by the most effective transport of Chinese outflow by the passage of frontal system (Hou et al., 2014; Kondo et al., 2008; Lim et al., 2012). The mode frequency was the greatest in winter, which was due to prevailing northerly winds accounting for $\sim 87 \%$ of that period. The main mode of winter and fall, and the second mode of summer monsoon season displayed similar concentrations, which comprised the primary mode of $\mathrm{O}_{3}$ distributions observed at IORS. $\mathrm{O}_{3}$ levels are known to exhibit lower variability at remote sites and rural areas (McKendry et al., 2014; Oltmans and Levy II, 1994). However, the results of this study challenge those of previous studies. $\mathrm{O}_{3}$ concentrations of IORS were highly dependent on air masses, upon which anthropogenic influence was highly variable. This finding emphasizes the significant role 

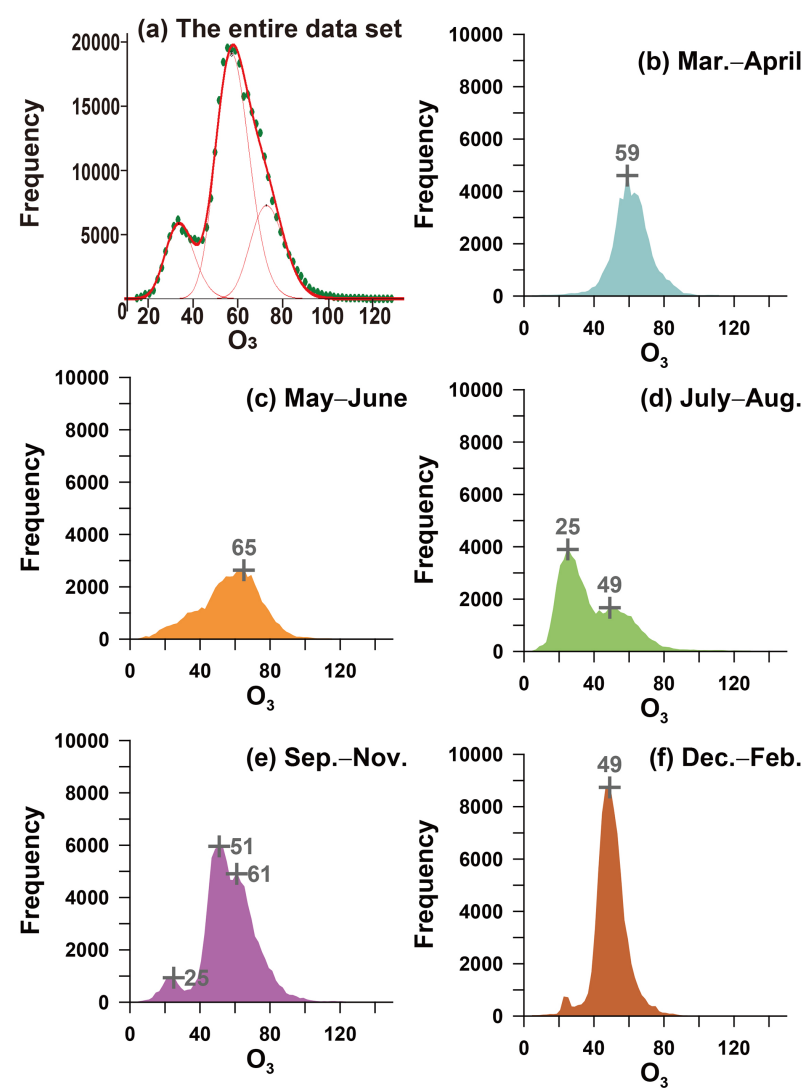

Figure 6. Frequency distributions of 10 min averaged $\mathrm{O}_{3}$ concentrations at IORS for (a) all data, (b) spring, (c) dry summer, (d) wet summer, (e) fall, and (f) winter with mode concentrations given.

of continental outflows in determining $\mathrm{O}_{3}$ concentrations in the northeast Asian region.

\section{Source signatures of $\mathrm{O}_{3}$}

\subsection{Cluster analysis of air mass trajectories}

Trajectories were divided into several groups using an agglomerative and hierarchical clustering algorithm with an average linkage function. Average linkage minimizes the within-cluster variance while maximizing between-cluster variance and has been identified as an effective method for categorizing different synoptic situations (Kalkstein et al., 1987). Within a cluster, the root-mean-square deviation (RMSD) of each trajectory from the cluster center was quantified and then summed to give the total root mean square deviation (TRMSD) (Cape et al., 2000). As a result, six trajectories were identified. The cluster analysis was performed using the Openair package in R (Carslaw and Ropkins, 2012, 2014). The distance matrix was calculated by the Euclidean distance.

The averaged backward trajectories of each cluster are presented in a map (Fig. 7). Among the six clusters, W was

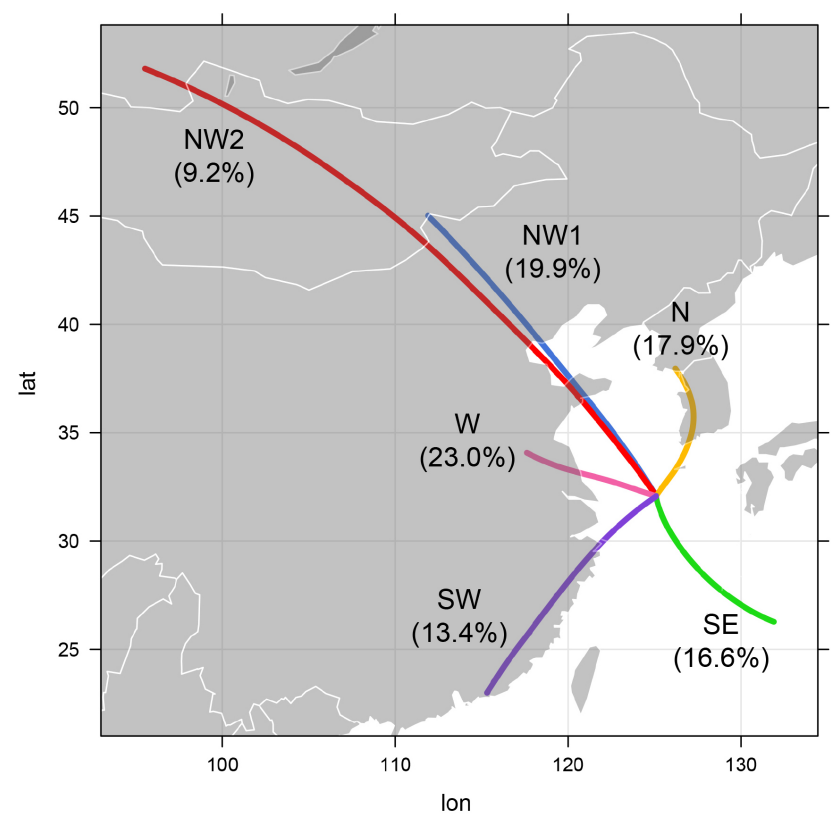

Figure 7. Mean trajectories of air masses classified into six groups. Air masses of $1500 \mathrm{~m}$ altitude were traced backward for $40 \mathrm{~h}$.

the most dominant $(23.0 \%)$, followed by NW1 (19.9\%), N $(17.9 \%)$, SE (16.6\%), SW (13.4 \%), and NW2 (9.2\%). The average $\mathrm{O}_{3}$ concentration was the highest for $\mathrm{N}(60 \mathrm{ppbv})$ and lowest for SE (40 ppbv). For the four clusters of continental air masses, the mean $\mathrm{O}_{3}$ concentrations were similar to the mean (52 ppbv) of the entire measurement set. In contrast, the marine air masses of SE and SW were characterized by low $\mathrm{O}_{3}$ concentrations, particularly during summer (32 ppbv).

\subsection{Source signature by CWT (concentration weighted trajectory) analysis}

The CWT (concentration weighted trajectory) method was employed to figure out the potential source of $\mathrm{O}_{3}$ observed at IORS. The concentration of $\mathrm{O}_{3}$ for each grid cell was calculated using the following equation (Carslaw, 2013):

$$
\ln \left(\bar{C}_{i j}\right)=\frac{1}{\sum_{l=1}^{N} \tau_{i j l}} \sum_{l=1}^{N} \ln \left(c_{l}\right) \tau_{i j l},
$$

where $i$ and $j$ indicate the indices of grid, $N$ shows the entire number of backward trajectories, $l$ represents the index of trajectory, $c_{l}$ signifies the concentration of $\mathrm{O}_{3}$ observed upon arrival of trajectory $l$, and $\tau_{i j l}$ is the residence time of trajectory $l$ in the grid cell $(i, j)$ (Carslaw, 2013; Cheng et al., 2013). In Fig. 8, the average $\mathrm{O}_{3}$ concentrations were presented over each grid cell. The $\mathrm{O}_{3}$ concentration was notably higher for NW1 when air mass passed through the Beijing region. The trajectory of NW2 was similar to that of NW1 


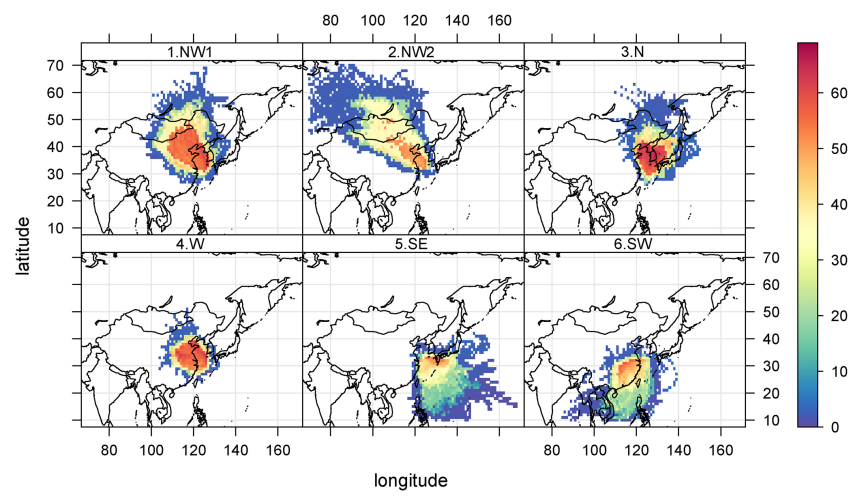

Figure 8. Concentration weighted trajectory (CWT) analysis of $\mathrm{O}_{3}$ concentrations (ppbv).

except for vertical movement, which is typical for air masses laden with Asian dusts (e.g., Kang et al., 2013).

Because the trajectory length is inversely proportional to the residence time of air in a grid cell, the clusters $\mathrm{N}$ and W represent stagnant conditions, which was favorable for $\mathrm{O}_{3}$ to build up. These two trajectories were constantly observed through the year with relatively less seasonal variation at IORS (Fig. 9b). Although the air masses of SW and SE originated from the Pacific Ocean, they were likely to pick urban emissions up when passing through southeastern China and south Japan, respectively. The result of CWT analysis confirms that the outflows from nearby lands were the source of $\mathrm{O}_{3}$ observed at IORS, of which the Chinese influence was the most dominant.

\subsection{Influence of Asian continental outflows}

For all clusters, the monthly variations of $\mathrm{O}_{3}$ concentrations were compared (Fig. 9a). In general, six clusters were similar in their annual pattern of $\mathrm{O}_{3}$, with higher concentrations in spring and fall and lower concentrations in summer. In contrast, for NW1, which passes through the Beijing metro area, $\mathrm{O}_{3}$ concentrations stayed high over $60 \mathrm{ppbv}$ during JulyAugust without considerable decrease (Fig. 9a). Although the summer concentrations in SE were low, below $30 \mathrm{ppbv}$, in spring and fall the $\mathrm{O}_{3}$ concentrations were high and comparable to those of NW1.

The influence of Chinese outflows, represented by NW1, NW2, and $\mathrm{W}$, was highest in winter, with a maximum occurrence $(86 \%)$ in December. The study region is under the influence of the Asian monsoon and is characterized by winds - southerly in summer and northerly in winter. The occurrence of maritime air, SE and SW, was the most frequent in summer monsoon season. The westerlies prevalent in this region are coupled with the steady occurrence of $\mathrm{W}$ through the year, implying a constant influence of Chinese outflows. The cluster $\mathrm{N}$ was commonly observed before and after the summer monsoon season, during which a stagnant condition often developed under the influence of migratory anticyclone (a)

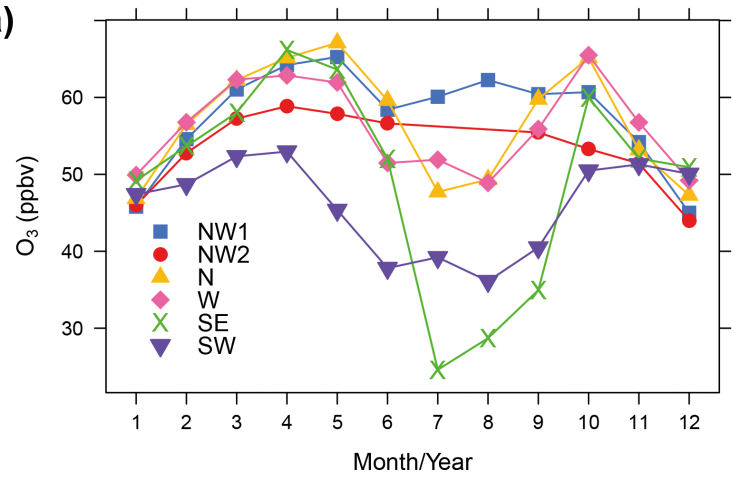

(b)

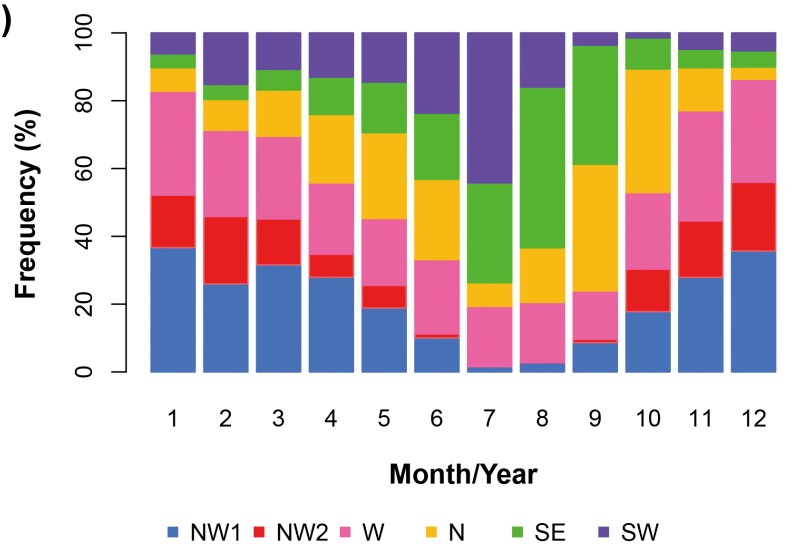

Figure 9. Monthly variations of (a) $\mathrm{O}_{3}$ concentrations of six clusters and (b) their monthly frequency.

systems. The stagnation tends to linger over the Yellow Sea, accumulating pollutants from nearby lands including China and Japan, as well as Korea. In fact, the high concentrations of $\mathrm{O}_{3}$ turned out to be associated with air trajectories from Chinese coastal regions. The model results of Zhao et al. (2009) also showed that the high concentration of $\mathrm{O}_{3}$ can be expanded under a high pressure system in east Asia.

The annual variation of each cluster was examined (Fig. 10a). As the $\mathrm{O}_{3}$ measurement began in June 2003, the measurements of 2003 were not included in this analysis. The yearly $\mathrm{O}_{3}$ concentrations increased from $49 \mathrm{ppbv}$ in 2004 to $55 \mathrm{ppbv}$ in 2009 and then decreased to $49 \mathrm{ppbv}$ in 2010 (Fig. 2). This pattern was not reflected in NW1 and NW2, for which annual means were the highest in 2004 and lowest in 2010. Marine air masses, including SE and SW, showed the most visible change during this period. Particularly, their annual frequencies increased in 2010, while those of clusters W, N, NW1 decreased (Fig. 10b). These results imply that marine air masses were likely to play a significant role in decreasing $\mathrm{O}_{3}$ concentration in 2010. The causes underlying increased occurrence of marine air masses need to be investigated further. These results suggest that a decrease in $\mathrm{O}_{3}$ concentrations after 2009 was not only associated with the decrease in $\mathrm{NO}_{x}$ emission from China, but also a change in meteorological state in the study region. 
(a)

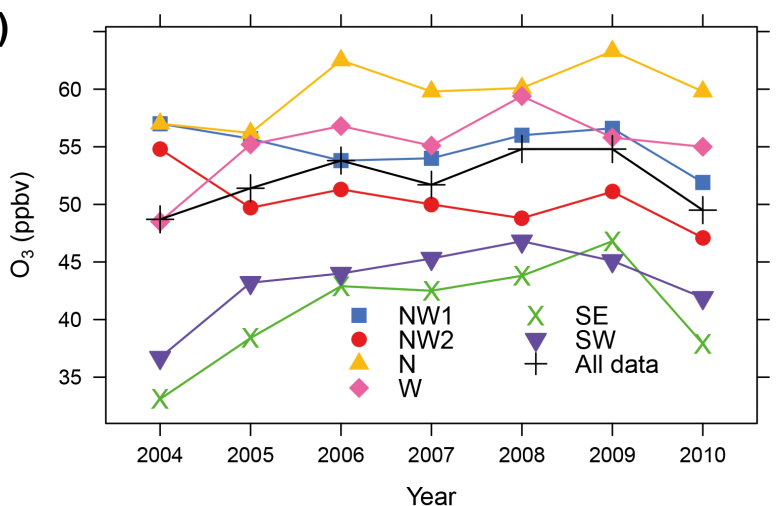

(b)

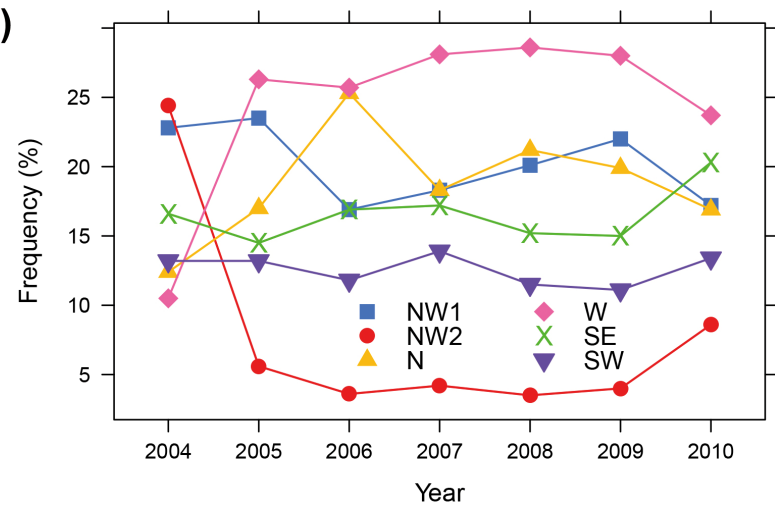

Figure 10. Annual variations of (a) $\mathrm{O}_{3}$ concentrations for six clusters and (b) their frequency.

Considering that Chinese influence is implicit in $\mathrm{N}$ and $\mathrm{SW}$, Chinese emission was the predominant factor determining the concentrations of $\mathrm{O}_{3}$ at IORS. The impact of Korean and Japanese emissions was incorporated in $\mathrm{N}$ and SE, apparent in spring and fall, respectively.

\section{Conclusion}

Surface $\mathrm{O}_{3}$ concentrations were determined at Ieodo Ocean Research Station (IORS) in the East China Sea $\left(32.07^{\circ} \mathrm{N}\right.$, $125.10^{\circ} \mathrm{E}$ ) from June 2003 to December 2010. The IORS is a $40 \mathrm{~m}$ research tower roughly equidistant from Korean, Chinese, and Japanese shores. The average concentration of $\mathrm{O}_{3}$ for the entire period was of $52 \pm 16 \mathrm{ppbv}$. It is higher than those of remote sites in northeast Asia and implies the steady influence of continental outflows. Particularly, the seasonal differences were prominent, with two peaks in April and October (62 ppbv) and a minimum in August (37 ppbv), which are greatly dependent on synoptic-scale circulation of the atmosphere which, except for summer, expedites effective transport of Asian outflows into the northwest Pacific region. The diurnal variation of $\mathrm{O}_{3}$ showed a broad maximum in late afternoon, resulting in $5 \mathrm{ppbv}$ of daytime build-up.

The cluster analysis of backward trajectories identified the six air masses affecting $\mathrm{O}_{3}$ concentrations at IORS. Among the six, four types of air masses originated from Asian continents, carrying their outflows (NW1, NW2, W, and N), and the other two were aged marine air from the Pacific Ocean (SE, SW). The $\mathrm{O}_{3}$ concentration of these continental and marine air masses was at a maximum (62 ppbv) in spring and at a minimum (32 ppbv) in summer, respectively. Particularly, the three clusters of NW1, NW2, and W, coming directly from mainland China, comprised $53 \%$ of all air masses which arrived at IORS, their contribution increasing up to $\sim 86 \%$ in winter. The clusters $\mathrm{N}$ and $\mathrm{W}$ were the most frequent under stagnant conditions before and after the summer monsoon. In summer, the occurrence of marine air reached the maximum $(\sim 74 \%)$. These results confirm that Chinese emissions were the dominant source of $\mathrm{O}_{3}$ observed at IORS.

The annual $\mathrm{O}_{3}$ concentrations increased until 2009, and then slightly decreased in 2010, which is in good accordance with $\mathrm{NO}_{x}$ observed in east Asia, where a slowdown of $\mathrm{NO}_{x}$ emission occurred in 2009 as a result of economic recession in China. In addition, the cluster analysis of air masses highlighted that the increased contribution of marine air masses also played a role in decreasing the mean concentration of $\mathrm{O}_{3}$ in 2010 .

Acknowledgements. This research was a part of the project titled "Construction of Ocean Research Stations and their Application Studies" funded by the Ministry of Oceans and Fisheries, Korea. We thank the people who contributed to establish IORS and who participated in field measurements. A part of this study was done for the Master's thesis of Beomcheol Shin.

Edited by: A. Perring

\section{References}

Akimoto, H., Mukai, H., Nishikawa, M., Murano, K., Hatakeyama, S., Liu, C.-M., Buhr, M., Hsu, K. J., Jaffe, D. A., Zhang, L., Honrath, R., Merrill, J. T., and Newell, R. E.: Long-range transport of ozone in the East Asian Pacific rim region, J. Geophys. Res.Atmos., 101, 1999-2010, doi:10.1029/95JD00025, 1996.

Ayers, G. P., Penkett, S. A., Gillett, R. W., Bandy, B., Galbally, I. E., Meyer, C. P., Elsworth, C. M., Bentley, S. T., and Forgan, B. W.: The annual cycle of peroxides and ozone in marine air at Cape Grim, Tasmania, J. Atmos. Chem., 23, 221-252, doi:10.1007/BF00055155, 1996.

Bell, J. N. B., Power, S. A., Jarraud, N., Agrawal, M., and Davies, C.: The effects of air pollution on urban ecosystems and agriculture, Int. J. Sustain. Dev. World, 18, 226-235, doi:10.1080/13504509.2011.570803, 2011.

Bell, M. L. and Dominici, F.: Effect modification by community characteristics on the short-term effects of ozone exposure and mortality in 98 US communities, Am. J. Epidemiol., 167, 986997, doi:10.1093/aje/kwm396, 2008

Berchet, A., Paris, J. D., Ancellet, G., Law, K. S., Stohl, A., Nédélec, P., Arshinov, M. Y., Belan, B. D., and Ciais, P.: Tropospheric ozone over Siberia in spring 2010: Remote in- 
fluences and stratospheric intrusion, Tellus B, 65, 19688, doi:10.3402/tellusb.v65i0.19688, 2013.

Brasseur, G. P., Orlando, J. J., and Tyndall, G. S.: Atmospheric chemistry and global change, Oxford University Press, New York, USA, 654 pp., 1999.

Cape, J. N., Methven, J., and Hudson, L. E.: The use of trajectory cluster analysis to interpret trace gas measurements at Mace Head, Ireland, Atmos. Environ., 34, 3651-3663, doi:10.1016/S1352-2310(00)00098-4, 2000.

Carslaw, D. C.: The openair manual - open-source tools for analyzing air pollution data, Manual for version 0.8-0, King's College London, UK, 2013.

Carslaw, D. C. and Ropkins, K.: openair - an R package for air quality data analysis, Environ. Modell. Softw., 27-28, 52-61, 2012.

Carslaw, D. C. and Ropkins, K.: openair: Open-source tools for the analysis of air pollution data, R package version 0.9-2, King's College London, UK, 2014.

Chan, C. Y., Chan, L. Y., Lam, K. S., Li, Y. S., Harris, J. M., and Oltmans, S. J.: Effects of Asian air pollution transport and photochemistry on carbon monoxide variability and ozone production in subtropical coastal South China, J. Geophys. Res., 107, 4746, doi:10.1029/2002JD002131, 2002.

Chang, H. H., Zhou, J., and Fuentes, M.: Impact of Climate Change on Ambient Ozone Level and Mortality in Southeastern United States, Int. J. Environ. Res., 7, 2866-2880, doi:10.3390/ijerph7072866, 2010.

Cheng, I., Zhang, L., Blanchard, P., Dalziel, J., and Tordon, R.: Concentration-weighted trajectory approach to identifying potential sources of speciated atmospheric mercury at an urban coastal site in Nova Scotia, Canada, Atmos. Chem. Phys., 13, 6031-6048, doi:10.5194/acp-13-6031-2013, 2013.

Cvitaš, T., Furger, M., Girgzdiene, R., Haszpra, L., Kezele, N., Klasinc, L., Planinšek, A., Pompe, M., Prevot, A. S. H., Scheel, H. E., and Schuepbach, E.: Spectral analysis of boundary layer ozone data from the EUROTRAC TOR network, J. Geophys. Res., 109, D02302, doi:10.1029/2003JD003727, 2004.

Draxler, R. R. and Rolph, G. D.: HYSPLIT (HYbrid Single-Particle Lagrangian Integrated Trajectory) Model access via NOAA ARL READY website, NOAA Air Resource Lab., Silver Spring, Md., USA, available at: http://www.arl.noaa.gov/ready/hysplit4.html (last access: 11 June 2015), 2003.

Dupont, R., Pierce, B., Worden, J., Hair, J., Fenn, M., Hamer, P., Natarajan, M., Schaack, T., Lenzen, A., Apel, E., Dibb, J., Diskin, G., Huey, G., Weinheimer, A., Kondo, Y., and Knapp, D.: Attribution and evolution of ozone from Asian wild fires using satellite and aircraft measurements during the ARCTAS campaign, Atmos. Chem. Phys., 12, 169-188, doi:10.5194/acp-12169-2012, 2012.

Fischer, E. V., Jaffe, D. A., and Weatherhead, E. C.: Free tropospheric peroxyacetyl nitrate (PAN) and ozone at Mount Bachelor: potential causes of variability and timescale for trend detection, Atmos. Chem. Phys., 11, 5641-5654, doi:10.5194/acp-115641-2011, 2011.

Gu, D., Wang, Y., Smeltzer, C., and Liu, Z.: Reduction in $\mathrm{NO}_{x}$ Emission Trends over China: Regional and Seasonal Variations, Environ. Sci. Technol., 47, 12912-12919, doi:10.1021/es401727e, 2013.

Hou, X., Zhu, B., Kang, H., and Gao, J.: Analysis of seasonal ozone budget and spring ozone latitudinal gradient variation in the boundary layer of the Asia-Pacific region, Atmos. Environ., 94, 734-741, doi:10.1016/j.atmosenv.2014.06.006, 2014.

Hou, X., Zhu, B., Fei, D., and Wang, D.: The impacts of summer monsoons on the ozone budget of the atmospheric boundary layer of the Asia-Pacific region, Sci. Total Environ., 502, 641649, doi:10.1016/j.scitotenv.2014.09.075, 2015.

Huang, J., Zhou, C., Lee, X., Bao, Y., Zhao, X., Fung, J., Richter, A., Liu, X., and Zheng, Y.: The effects of rapid urbanization on the levels in tropospheric nitrogen dioxide and ozone over East China, Atmos. Environ., 77, 558-567, 2013.

Hwang, G., Lee, M., Shin, B., Lee, G., Lee, J., and Shim, J.: Mass Concentration and Ionic Composition of $\mathrm{PM}_{2.5}$ Observed at Ieodo Ocean Research Station, Korean J. Atmos. Environ., 24, 501-511, 2008 (in Korean with English abstract).

IPCC: Climate Change 2013: The Physical Science Basis, Intergovernmental Panel on Climate Change, edited by: Stocker, T. F., Qin, D., Plattner, G.-K., Tignor, M., Allen, S. K., Boschung, J., Nauels, A., Xia, Y., Bex, V., and Midgley, P. M., Cambridge University Press, Cambridge, UK, 1535 pp., 2013.

Itahashi, S., Uno, I., Irie, H., Kurokawa, J.-I., and Ohara, T.: Regional modeling of tropospheric $\mathrm{NO}_{2}$ vertical column density over East Asia during the period 2000-2010: comparison with multisatellite observations, Atmos. Chem. Phys., 14, 3623-3635, doi:10.5194/acp-14-3623-2014, 2014.

Jacobson, M. Z.: Air Pollution and Global Warming: History, Science, and Solutions, 2nd Edn., Cambridge University Press, Cambridge, UK, 406 pp., 2012.

Jaffe, D. A., Honrath, R. E., Zhang, L., Akimoto, H., Shimizu, A., Mukai, H., Murano, K., Hatakeyama, S., and Merrill, J.: Measurements of $\mathrm{NO}, \mathrm{NOy}, \mathrm{CO}$ and $\mathrm{O}_{3}$ and estimation of the ozone production rate at Oki Island, Japan, during PEM-West, J. Geophys. Res.-Atmos., 101, 2037-2048, doi:10.1029/95JD01699, 1996.

Kalkstein, L. S., Tan, G., and Skindlov, J. A.: An Evaluation of Three Clustering Procedures for Use in Synoptic Climatological Classification, J. Clim. Appl. Meteorol., 26, 717-730, doi:10.1175/1520-0450(1987)026<0717:AEOTCP>2.0.CO;2, 1987.

Kanaya, Y., Tanimoto, H., Yokouchi, Y., Taketani, F., Komazaki, Y., Irie, H., Takashima, H., Pan, X., Nozoe, S., and Inomata, S.: Diagnosis of Photochemical Ozone Production Rates and Limiting Factors in Continental Outflow Air Masses Reaching Fukue Island, Japan: Ozone-Control Implications, Aerosol Air Qual. Res., in press, doi:10.4209/aaqr.2015.04.0220, 2015.

Kang, E., Han, J., Lee, M., Lee, G., and Kim, J. C.: Chemical characteristics of size-resolved aerosols from Asian dust and haze episode in Seoul Metropolitan City, Atmos. Res., 127, 34-46, doi:10.1016/j.atmosres.2013.02.002, 2013.

Karnosky, D. F., Skelly, J. M., Percy, K. E., and Chappelka, A. H.: Perspectives regarding 50 years of research on effects of tropospheric ozone air pollution on US forests, Environ. Pollut., 147, 489-506, doi:10.1016/j.envpol.2006.08.043, 2007.

Kato, S., Pochanart, P., and Kajii, Y.: Measurements of ozone and nonmethane hydrocarbons at Chichi-jima island, a remote island in the western Pacific: long-range transport of polluted air from the Pacific rim region, Atmos. Environ., 35, 6021-6029, doi:10.1016/S1352-2310(01)00453-8, 2001.

Kondo, Y., Hudman, R. C., Nakamura, K., Koike, M., Chen, G., Miyazaki, Y., Takegawa, N., Blake, D. R., Simpson, I. J., Ko, M., 
Kita, K., Shirai, T., and Kawakami, S.: Mechanisms that influence the formation of high-ozone regions in the boundary layer downwind of the Asian continent in winter and spring, J. Geophys. Res., 113, D15304, doi:10.1029/2007JD008978, 2008.

Kotchenruther, R. A., Jaffe, D. A., Beine, H. J., Anderson, T. L., Bottenheim, J. W., Harris, J. M., Blake, D. R., and Schmitt, R.: Observations of ozone and related species in the Northeast Pacific during the PHOBEA campaigns: 2. Airborne observations, J. Geophys. Res., 106, 7463-7483, doi:10.1029/2000JD900425, 2001.

Lim, S., Lee, M., Lee, G., Kim, S., Yoon, S., and Kang, K.: Ionic and carbonaceous compositions of $\mathrm{PM}_{10}, \mathrm{PM}_{2.5}$ and $\mathrm{PM}_{1.0}$ at Gosan ABC Superstation and their ratios as source signature, Atmos. Chem. Phys., 12, 2007-2024, doi:10.5194/acp-12-20072012, 2012.

Lin, M., Fiore, A. M., Horowitz, L. W., Cooper, O. R., Naik, V., Holloway, J., Johnson, B. J., Middlebrook, A. M., Oltmans, S. J., Pollack, I. B., Ryerson, T. B., Warner, J. X., Wiedinmyer, C., Wilson, J., and Wyman, B.: Transport of Asian ozone pollution into surface air over the western United States in spring, J. Geophys. Res., 117, D00V07, doi:10.1029/2011jd016961, 2012.

McKendry, I., Christensen, E., Schiller, C., Vingarzan, R., Macdonald, A. M., and Li, Y.: Low Ozone Episodes at Amphitrite Point Marine Boundary Layer Observatory, British Columbia, Canada, Atmos. Ocean, 52, 271-280, doi:10.1080/07055900.2014.910164, 2014.

Monks, P. S., Granier, C., Fuzzi, S., Stohl, A., Williams, M. L., Akimoto, H., Amann, M., Baklanov, A., Baltensperger, U., Bey, I., Blake, N., Blake, R. S., Carslaw, K., Cooper, O. R., Dentener, F., Fowler, D., Fragkou, E., Frost, G. J., Generoso, S., Ginoux, P., Grewe, V., Guenther, A., Hansson, H. C., Henne, S., Hjorth, J., Hofzumahaus, A., Huntrieser, H., Isaksen, I. S. A., Jenkin, M. E., Kaiser, J., Kanakidou, M., Klimont, Z., Kulmala, M., Laj, P., Lawrence, M. G., Lee, J. D., Liousse, C., Maione, M., McFiggans, G., Metzger, A., Mieville, A., Moussiopoulos, N., Orlando, J. J., O'Dowd, C. D., Palmer, P. I., Parrish, D. D., Petzold, A., Platt, U., Pöschl, U., Prévôt, A. S. H., Reeves, C. E., Reimann, S., Rudich, Y., Sellegri, K., Steinbrecher, R., Simpson, D., ten Brink, H., Theloke, J., van der Werf, G. R., Vautard, R., Vestreng, V., Vlachokostas, C., and von Glasow, R.: Atmospheric composition change - global and regional air quality, Atmos. Environ., 43, 5268-5350, doi:10.1016/j.atmosenv.2009.08.021, 2009.

Moon, I.-J., Shim, J.-S., Lee, D. Y., Lee, J. H., Min, I.-K., and Lim, K. C.: Typhoon Researches Using the Ieodo Ocean Research Station : Part1. Importance and Present Status of Typhoon Observation, Atmosphere (Korean Meteorological Society), 20, 247260, 2010 (in Korean with English abstract).

Ohara, T., Akimoto, H., Kurokawa, J., Horii, N., Yamaji, K., Yan, X., and Hayasaka, T.: An Asian emission inventory of anthropogenic emission sources for the period 1980-2020, Atmos. Chem. Phys., 7, 4419-4444, doi:10.5194/acp-7-4419-2007, 2007.

Oltmans, S. J. and Levy II, H.: Surface ozone measurements from a global network, Atmos. Environ., 28, 9-24, doi:10.1016/13522310(94)90019-1, 1994.

Parrish, D. D., Millet, D. B., and Goldstein, A. H.: Increasing ozone in marine boundary layer inflow at the west coasts of North America and Europe, Atmos. Chem. Phys., 9, 1303-1323, doi:10.5194/acp-9-1303-2009, 2009.
Parrish, D. D., Law, K. S., Staehelin, J., Derwent, R., Cooper, O. R., Tanimoto, H., Volz-Thomas, A., Gilge, S., Scheel, H.-E., Steinbacher, M., and Chan, E.: Long-term changes in lower tropospheric baseline ozone concentrations at northern mid-latitudes, Atmos. Chem. Phys., 12, 11485-11504, doi:10.5194/acp-1211485-2012, 2012.

$\mathrm{R}$ Core Team: A language and environment for statistical computing. R Foundation for Statistical Computing, Vienna, Austria, available at: http://www.R-project.org/ (last access: 11 June 2015), 2014.

Ridder, T., Gerbig, C., Notholt, J., Rex, M., Schrems, O., Warneke, T., and Zhang, L.: Ship-borne FTIR measurements of $\mathrm{CO}$ and $\mathrm{O}_{3}$ in the Western Pacific from $43^{\circ} \mathrm{N}$ to $35^{\circ} \mathrm{S}$ : an evaluation of the sources, Atmos. Chem. Phys., 12, 815-828, doi:10.5194/acp-12815-2012, 2012.

Safieddine, S., Clerbaux, C., George, M., Hadji-Lazaro, J., Hurtmans, D., Coheur, P. F., Wespes, C., Loyola, D., Valks, P., and Hao, N.: Tropospheric ozone and nitrogen dioxide measurements in urban and rural regions as seen by IASI and GOME-2, J. Geophys. Res., 118, 10555-10566, 2013.

Schaub, M., Skelly, J. M., Zhang, J. W., Ferdinand, J. A., Savage, J. E., Stevenson, R. E., Davis, D. D., and Steiner, K. C.: Physiological and foliar symptom response in the crowns of Prunus serotina, Fraxinus americana and Acer rubrum canopy trees to ambient ozone under forest conditions, Environ. Pollut., 133, 553-567, doi:10.1016/j.envpol.2004.06.012, 2005.

Seinfeld, J. H. and Pandis, S. N.: Atmospheric Chemistry and Physics: From Air Pollution to Climate Change, 2nd Edn., John Wiley and Sons, New York, USA, 2006.

Shim, J. H., Chun, I. S., and Min, I. K.: Construction of Ieodo Ocean Research Station and its operation, The Proceedings of the 14th International Offshore and Polar Engineering Conference, 2328 May 2004, Toulon, France, 140, 13-11, 2004.

Shin, B., Lee, M., Lee, J., and Shim, J. S.: Seasonal and Diurnal Variations of Surface Ozone at Ieodo in the East China Sea, Korean J. Atmos. Environ., 23, 631-639, 2007 (in Korean with English abstract).

Tanimoto, H., Sawa, Y., Matsueda, H., Uno, I., Ohara, T., Yamaji, K., Kurokawa, J.-I., and Yonemura, S.: Significant latitudinal gradient in the surface ozone spring maximum over East Asia, Geophys. Res. Lett., 32, L21805, doi:10.1029/2005GL023514, 2005.

Tanimoto, H., Sawa, Y., Yonemura, S., Yumimoto, K., Matsueda, H., Uno, I., Hayasaka, T., Mukai, H., Tohjima, Y., Tsuboi, K., and Zhang, L.: Diagnosing recent $\mathrm{CO}$ emissions and ozone evolution in East Asia using coordinated surface observations, adjoint inverse modeling, and MOPITT satellite data, Atmos. Chem. Phys., 8, 3867-3880, doi:10.5194/acp-8-3867-2008, 2008.

Tanimoto, H., Ohara, T., and Uno, I.: Asian anthropogenic emissions and decadal trends in springtime tropospheric ozone over Japan: 1998-2007, Geophys. Res. Lett., 36, L23802, doi:10.1029/2009GL041382, 2009.

Wada, A., Matsueda, H., Sawa, Y., Tsuboi, K., and Okubo, S.: Seasonal variation of enhancement ratios of trace gases observed over 10 years in the western North Pacific, Atmos. Environ., 45, 2129-2137, 2011.

Walker, T. W., Martin, R. V., van Donkelaar, A., Leaitch, W. R., MacDonald, A. M., Anlauf, K. G., Cohen, R. C., Bertram, T. H., Huey, L. G., Avery, M. A., Weinheimer, A. J., Flocke, F. M., Tara- 
sick, D. W., Thompson, A. M., Streets, D. G., and Liu, X.: TransPacific transport of reactive nitrogen and ozone to Canada during spring, Atmos. Chem. Phys., 10, 8353-8372, doi:10.5194/acp10-8353-2010, 2010.

Wang, X. and Mauzerall, D. L.: Characterizing distributions of surface ozone and its impact on grain production in China, Japan and South Korea: 1990 and 2020, Atmos. Environ., 38, 43834402, doi:10.1016/j.atmosenv.2004.03.067, 2004.

Watanabe, K., Nojiri, Y., and Kariya, S.: Measurements of ozone concentrations on a commercial vessel in the marine boundary layer over the northern North Pacific Ocean, J. Geophys. Res., 110, D11310, doi:10.1029/2004JD005514, 2005.

Weiss-Penzias, P., Jaffe, D. A., Jaeglé, L., and Liang, Q.: Influence of long-range-transported pollution on the annual and diurnal cycles of carbon monoxide and ozone at Cheeka Peak Observatory, J. Geophys. Res., 109, D23S14, doi:10.1029/2004JD004505, 2004.

Yamaji, K., Ohara, T., Uno, I., Tanimoto, H., Kurokawa, J.I., and Akimoto, H.: Analysis of the seasonal variation of ozone in the boundary layer in East Asia using the Community Multi-scale Air Quality model: What controls surface ozone levels over Japan?, Atmos. Environ., 40, 1856-1868, doi:10.1016/j.atmosenv.2005.10.067, 2006.
Zhang, L., Jacob, D. J., Boersma, K. F., Jaffe, D. A., Olson, J. R., Bowman, K. W., Worden, J. R., Thompson, A. M., Avery, M. A., Cohen, R. C., Dibb, J. E., Flock, F. M., Fuelberg, H. E., Huey, L. G., McMillan, W. W., Singh, H. B., and Weinheimer, A. J.: Transpacific transport of ozone pollution and the effect of recent Asian emission increases on air quality in North America: an integrated analysis using satellite, aircraft, ozonesonde, and surface observations, Atmos. Chem. Phys., 8, 6117-6136, doi:10.5194/acp-8-6117-2008, 2008.

Zhao, B., Wang, S. X., Liu, H., Xu, J. Y., Fu, K., Klimont, Z., Hao, J. M., He, K. B., Cofala, J., and Amann, M.: $\mathrm{NO}_{x}$ emissions in China: historical trends and future perspectives, Atmos. Chem. Phys., 13, 9869-9897, doi:10.5194/acp-13-9869-2013, 2013.

Zhao, C., Wang, Y., and Zeng, T.: East China plains: A "basin" of ozone pollution, Environ. Sci. Technol., 43, 1911-1915, 2009. 